\title{
NUTRITIVE VALUE AND SENSORY ACCEPTABILITY OF CORN- AND KOCHO-BASED FOODS SUPPLEMENTED WITH LEGUMES FOR INFANT FEEDING IN SOUTHERN ETHIOPIA
}

\author{
Yewelsew Abebe ${ }^{1}$, Barbara J. Stoecker ${ }^{2 *}$, Margaret J. Hinds ${ }^{2}$, Gail E. Gates ${ }^{2}$
}

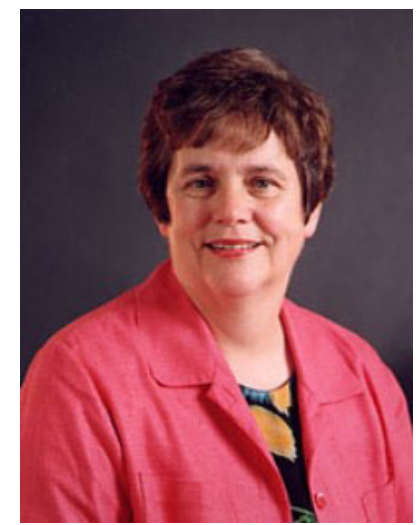

Barbara J. Stoecker

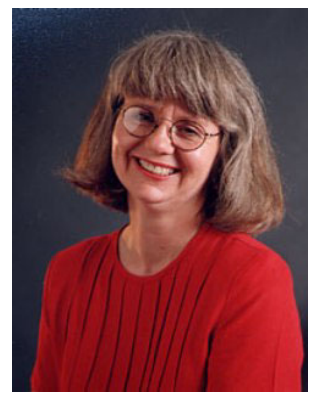

Gail E. Gates

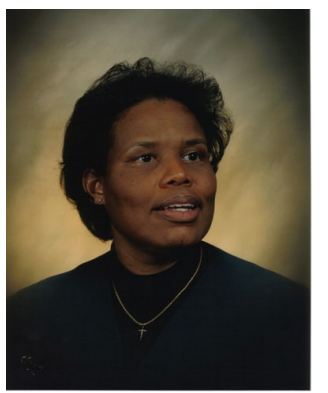

Margaret J. Hinds

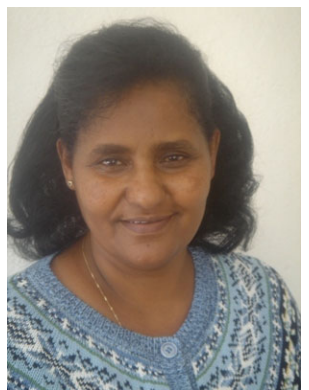

Yewelsew Abebe

${ }^{1}$ Department of Rural Development and Family Sciences, Debub University, P.O.Box 5, Fax: 251-6-205421, Ethiopia

${ }^{2}$ Corresponding Author. Department of Nutritional Sciences, 301 Human Environmental Sciences, Oklahoma State University, 74078-6141, Fax: 405-744-1357, USA. Address for Correspondence: 301 Human Environmental Sciences, Department of Nutritional Sciences, Oklahoma State University, Stillwater, OK 74078, USA. Email: Barbara.Stoecker@okstate.edu 


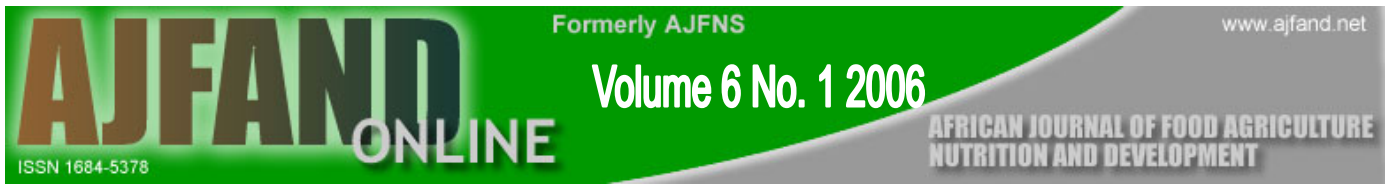

\section{ABSTRACT}

In most developing countries, complementary foods are based on staple cereal or root crops. Imported or commercially developed foods generally are not used by low-income rural households due to high cost and poor availability. To improve the quality of children's diets in Southern Ethiopia, two complementary foods were formulated based on corn, or on an indigenous root crop (Enset ventricosum) product called kocho. Kidney beans and pumpkin pulp were used to improve the protein and vitamin A values, respectively. Kidney beans and corn were soaked, germinated and lightly roasted before grinding. Four formulations of complementary foods were prepared. Two of them were traditional corn- or kocho-based, and served as controls. The other two were supplemented formulations, and contained either corn:kidney bean:pumpkin (CBP) or kocho:kidney bean:pumpkin (KBP). Crude protein and fat, amino acid profile, and carotene content of the corn, kocho, kidney bean, and pumpkin were determined by standard AOAC methods. The four formulations were evaluated for sensory acceptability in Southern Ethiopia by mother and child pairs. The CBP and KBP formulations had crude protein contents of $14.07 \mathrm{~g} / 100 \mathrm{~g}$ and 13.81 $\mathrm{g} / 100 \mathrm{~g}$, respectively, while the traditional corn and kocho had only $8.82 \mathrm{~g} / 100 \mathrm{~g}$ and $1.46 \mathrm{~g} / 100 \mathrm{~g}$, on a dry weight basis. Adding kidney beans to both mixtures improved their essential amino acid profiles, but the need to serve the foods as thin porridge for infants created low energy density products. The pumpkin in CBP and KBP provided $54 \mu \mathrm{g}$ RAE per $100 \mathrm{kcal}$, increasing the Vitamin A value of the mixes by 25- and 180-fold, respectively. Sensory evaluation of CBP by 30 mother and child pairs, and KBP by 28 pairs indicated high acceptability (4.7 - 4.9 on a 5-pt Hedonic scales) of the complementary foods. Acceptability scores of CBP and KBP were not significantly different $(p>0.05)$ from those of the traditional corn and kocho formulations. Thus, addition of kidney beans and pumpkin is a potential way to increase the nutritive value of traditional Ethiopian complementary foods prepared from corn or kocho.

Key words: Amino acid profile, legume, nutrient density, complementary foods, vitamin A

French

Valeur nutritive et acceptabilité sensorielle des aliments à base de maïs et de kocho complétés par des légumineuses pour l'alimentation des bébés dans la région sud de

\section{l'Ethiopie}

Résumé

Dans la plupart des pays en développement, les aliments de transition sont basés sur des céréales comme aliment de base ou sur des plantes racines. Les aliments importés ou préparés commercialement ne sont généralement pas utilisés par des ménages à bas revenus parce que ces aliments coûtent cher et ne sont pas toujours disponibles. Pour améliorer la qualité de l'alimentation des enfants dans la région sud de l'Ethiopie,

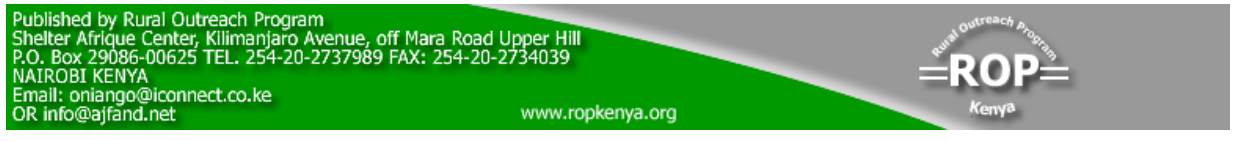




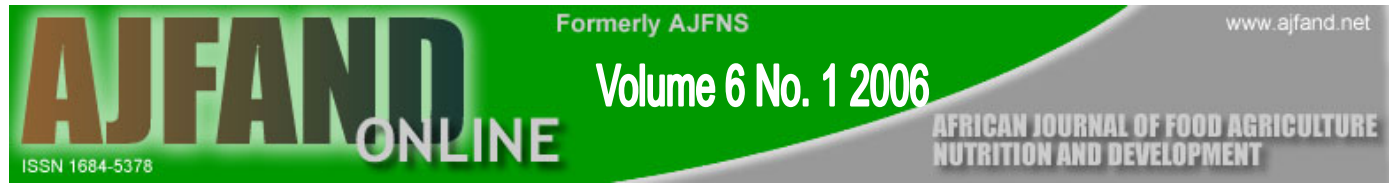

deux aliments de transition ont été formulés à partir du maïs ou d'un produit d'une plante racine indigène (Enset ventricosum) appelée kocho. Des haricots et la pulpe de courge ont été utilisés pour augmenter les teneurs en protéines et en vitamine A respectivement. Les haricots et le maïs ont été trempés dans l'eau, germinés et légèrement grillés avant d'être moulus. Quatre préparations d'aliments de transition ont été préparées. Deux d'entre elles étaient basées sur du maïs traditionnel ou kocho et servaient de contrôles. Les deux autres ont servi de formulations supplémentaires, et elles contenaient des proportions de maïs:haricot haricot:courge (MHC) ou kocho:haricot haricot:courge (KHC). Les protéines et les graisses brutes, l'aminogramme, et la teneur en carotène du maïs, du kocho, du haricot et de la courge ont été déterminés par des méthodes uniformes AOAC. Les quatre formulations ont été évaluées pour détecter l'acceptabilité sensorielle dans la région sud de l'Ethiopie par des pairs composées de mèrelenfant. Les formulations MHC et KHC avaient des teneurs en protéines brutes de 14,07 $\mathrm{g} / 100 \mathrm{~g}$ et 13,81 $\mathrm{g} / 100 \mathrm{~g}$, respectivement, tandis que le maïs traditionnel et le kocho n'avaient que $8,82 \mathrm{~g} / 100 \mathrm{~g}$ et $1,46 \mathrm{~g} / 100 \mathrm{~g}$, en se basant sur le poids sec. En ajoutant des haricots aux deux mélanges, leurs aminogrammes essentiels ont été sensiblement améliorés mais la nécessité de servir ces aliments comme porridge léger pour les bébés a créé des produits de basse densité de l'énergie. La courge dans le KHC et le MHC a donné $54 \mu \mathrm{g} A E$ par $100 \mathrm{kcal}$, augmentant ainsi la valeur de la Vitamine $A$ des mélanges de 25 et 180 fois respectivement. L'évaluation sensorielle du MHC par 30 pairs de mèrelenfant, et du KHC par 28 pairs a indiqué une acceptabilité élevée (4,7 - 4,9 sur une échelle Hédonique de 5-pt) des aliments de transition. Les scores de l'acceptabilité du MHC et $d u$ KHC n'ont pas été très différents $(p>0,05)$ de ceux des formulations du maïs et $d u$ kocho traditionnels. Ainsi, l'addition des haricots et de la courge est un moyen susceptible d'augmenter la valeur nutritive des aliments traditionnels éthiopiens de transition préparés à partir du maïs ou du kocho.

Mots-clés: aminogramme, légumineuse, densité en nutriments, aliments de transition, vitamine A

\section{INTRODUCTION}

Children in most developing countries are introduced directly to the regular household diet made of cereal or starchy root crops. Inadequate complementary food is a major cause for the high incidence of child malnutrition, morbidity and mortality in many developing countries [1]. The weaning period is the most critical period in a child's life $[1,2,3,4]$. As infants transfer from nutritious and uncontaminated breast milk to the regular family diet, they become vulnerable to malnutrition and disease. In developing countries, foods are rarely modified at the household level to increase nutrient density to meet the needs of infants [2]. Traditional infant foods made of cereals or tubers may be low in several nutrients including protein, vitamin A, zinc and iron; these nutrients are of special importance due to their impact on physical and cognitive development [4, $5,6]$. Furthermore, the bulkiness of traditional weaning foods and high concentrations

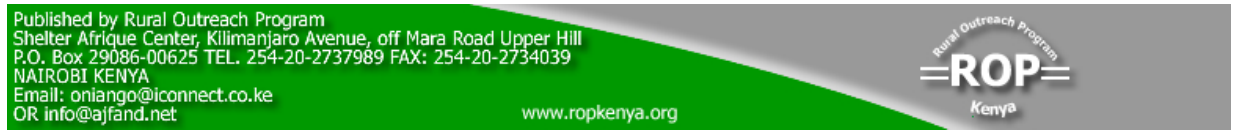


of fiber and inhibitors are major factors reducing their nutritional benefits $[6,7,8,9]$. As a result, studies have shown that growth faltering in children coincides with the introduction of low-nutrient-density weaning foods, improper feeding practices and gastrointestinal infections [10]. Mothers may need education on the importance of complementary foods and about hygienic processing, preparation and storage of these foods [10]. Infant foods in many parts of Ethiopia are cereal or root crop-based because these are major components of the family's diet $[11,12]$.

Development of complementary foods is guided by the following principles: 1) high nutritional value to supplement breastfeeding, 2) acceptability, 3) low price, and 4) use of local food items [2, 13]. The participation of young children's mothers in complementary food formulation and acceptability testing encourages caretakers to gain nutrition knowledge and positive attitudes towards dietary improvement [13]. Ideally, complementary foods should contain animal source foods with high biological value to foster growth and development $[4,5]$. However, these foods may not be available to most low-income households in developing countries.

Recommending commercial weaning foods may not be feasible due to limited income and inaccessibility. A survey on 334 mother and child pairs in Tigray, Ethiopia reported that no child received the cereal-based nutritious complementary food produced commercially in Ethiopia [12]. A practical alternative used in various countries is the supplementation of locally grown food crops with legumes, along with the addition of vegetables or fruits to enhance vitamin concentration $[14,15]$. The objectives of this study were; a) to develop two complementary foods supplemented with legume and pumpkin pulp to improve protein and vitamin A content of traditional foods, and b) to determine acceptability of the supplemented foods to local mothers and children.

\section{MATERIALS AND METHODS}

\section{Selection and Analysis of Foods}

For a pilot study in Sidama, twelve women were identified by the local Ministry of Agriculture staff and by members of the farmers' association as persons who would be knowledgeable about food preparation and child-rearing practices in the village. Subsequently, these women agreed to be interviewed, and they identified corn (Zea mays), kocho (Enset ventricosum), kidney beans (Vicia faba) and pumpkin (Cucurbita pepo) as common household food items that could be fed to children.

Corn, kocho, kidney beans and pumpkin obtained from Ethiopian local markets were sent for analysis to the Agricultural Experimental Station Chemical Laboratories, University of Missouri, Columbia, USA. Duplicate samples of the foods (corn, kidney beans, kocho, and pumpkin) were analyzed using standard methods of the Association of Official Analytical Chemists (AOAC) for crude protein [Method \#990.03], amino acid profile [Method \#982.30E (a, b, c)], crude fat [Method \#920.39 (A)], and carotenes [Method \#970.64]. Results were used to formulate complementary foods with 


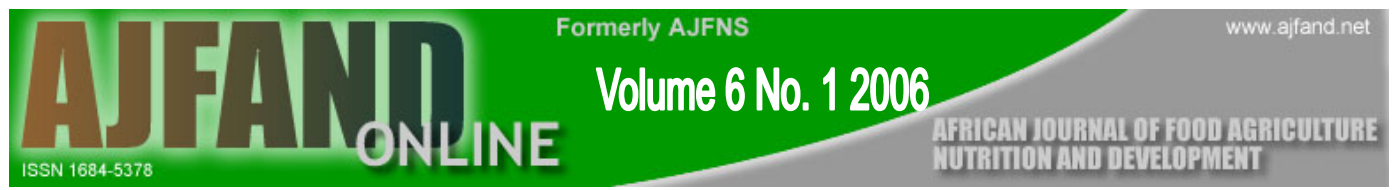

improved protein density, amino acid patterns and vitamin A, value to better meet the needs of infants transitioning from breast milk to family food.

\section{Formulation and Preparation of Complementary Food Mixtures}

Three Ethiopian mothers from the rural study area assisted with food purchase and processing, and with demonstrating preparation of the complementary foods to other mothers. Corn and kidney beans, obtained locally, were soaked separately in potable water for six hours, drained, then germinated at room temperature for 48 and 24 hours, respectively [14]. The germinated seeds were rinsed and partially dried in the sun for one hour to facilitate removal of the hulls. Kidney beans were de-hulled manually; and corn grains were lightly pounded to remove the hulls. The dehulled grains were milled in local mills to particle sizes ranging from $0.6 \mathrm{~mm}$ to $1.0 \mathrm{~mm}$ in diameter. Kocho was sun dried, crumbled, and passed through a household sieve to reduce fiber. Pumpkin was peeled and chopped into approximately $2 \mathrm{~cm}$ pieces that were boiled and mashed for preparing the complementary foods.

Two supplemented complementary food mixtures, corn:kidney bean:pumpkin (CBP) and kocho:kidney bean:pumpkin (KBP), were formulated and compared to the unsupplemented products (Table 1). Corn and kidney beans were germinated to improve bioavailability of minerals, and to minimize fuel use and cooking time. Kidney beans were added to complement the low protein content/quality of the commonly used staple crops, ie, kocho and corn. Pumpkin was included to contribute to the vitamin A value. Corn oil increased the energy density of the food. However, only one teaspoon (4 g) of oil was added to the supplemented formulations (Table 1) due to severe resource limitations of these mothers. Corn and kocho prepared identically, but without additional ingredients, served as controls to allow mothers and children to compare sensory attributes of each product.

\section{Sensory Evaluation}

Approval for all procedures (namely sensory testing methods and materials, evaluation instruments, and data collection methods) was obtained from the Oklahoma State University Institutional Review Board. Approvals in Awassa, Ethiopia, were also obtained from Debub University, Bushulo Health Center, the Ministry of Agriculture, and the Farmer's Association Office in the study area. Sensory evaluation was carried out in Southern Ethiopia in July 2002. Panelists were recruited from among mothers of malnourished children (6 - 48 months old) from out-station vaccination programs of Bushulo Health Center. Children were considered to be malnourished if their weight was at least 2.5 standard deviations below the mean weight for age. For example a one year old male would be considered malnourished if his weight was less than $7.6 \mathrm{~kg}$.

After giving consent, 58 women and their children, who were attending child feeding classes at the nutrition unit of the Bushulo Health Service in Sidama, Southern Ethiopia - were selected for the study. Participating children were still breast fed but had already been introduced to semisolid or solid food. Prior to conducting the sensory tests,

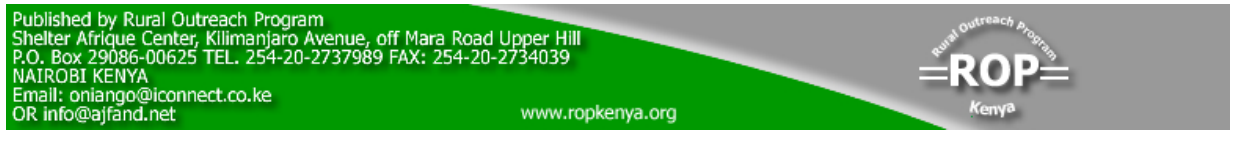


mothers were explained to, the objectives of the study, and instructed to give their honest opinions after tasting the food mixtures and feeding them to their children.

Affective sensory testing using the central location method was carried out at the Bushulo Health Center in Sidama [16]. Due to the challenges of administering a twoproduct random design in a busy rural community health center, panelists came to the center on two different days to test the samples. Twenty eight mother and child pairs evaluated the kocho-based products and 30 mother and child pairs evaluated corn-based products. Mothers and children were given the complementary foods supplemented with kidney beans and pumpkin pulp on day one and the traditional complementary foods on day two. Each participant tested only two products (corn or kocho with and without legume and pumpkin). Twenty-eight to thirty mother and child pairs evaluated each supplemented product as well as its corresponding control. This experimental design enabled appropriate inferences to be obtained on acceptability of control (traditional) versus supplemented food for each product type.

On a test day, each mother was given a 100 g portion of the complementary porridge ready-to-eat to her child, and was asked to return any leftover food to the interviewers. Mothers evaluated the foods for appearance, smell, taste, and consistency using fivepoint Hedonic scales (from " 5 " - like very much, to " 1 " - dislike very much). Mothers also commented on additional attributes of the foods such as the child's preference or after-taste discomforts, and suggested price and purchase intent. To facilitate data collection, the sensory evaluation instruments were translated from English to Amharic, which was commonly understood by the technical team and the panelists. Each sensory questionnaire included the following; demographic information on mother and child consumption frequency information of ingredients in the samples, child's behavior during and after eating each sample; standard five-point Hedonic scales evaluating degree of liking of appearance, smell, taste, and consistency/mouth-feel when swallowing, and purchase intent questions.

\section{Data Analysis}

Descriptive data were compiled using the SPSS software program [17]. Means and standard deviations were calculated for acceptability of the sensory attributes of the complementary foods. A one-way analysis of variance (ANOVA) was conducted to test for significant differences $(p<0.05)$ in the sensory attributes (appearance, smell, taste, and consistency/mouth-feel) between legume-supplemented and traditional complementary foods.

\section{RESULTS}

\section{Energy and Nutrient Density}

Energy, protein and vitamin A densities of the complementary foods are shown in Table 2. Energy densities of CBP and KBP porridges $(0.48 \mathrm{kcal} / \mathrm{g}$ and $0.46 \mathrm{kcal} / \mathrm{g}$ as served, respectively) were lower than the traditional corn $(0.53 \mathrm{kcal} / \mathrm{g})$ and kocho $(0.49$ $\mathrm{kcal} / \mathrm{g}$ ) porridge foods at least partially because more liquid was required to obtain a 
consistency similar to the unsupplemented products; this extra water resulted in a lower energy density.

Both legume-supplemented products had much higher total protein concentrations on a dry-weight basis than traditional products as illustrated in Figure 1.

Figure Legends

Figure 1 Protein concentration (g/100 g dry weight) of traditional and legumesupplemented complementary foods

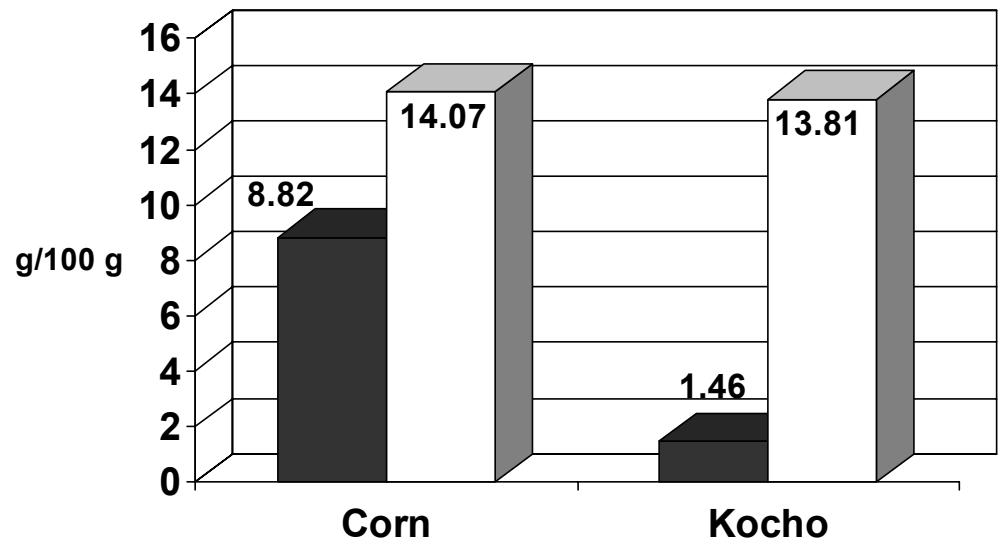

$\square$ Traditional $\square$ Supplemented

The protein density (energy from protein as percentage of total energy) for legumesupplemented corn (CBP) was $14.7 \%$ while the unsupplemented corn was $8.4 \%$. For legume-supplemented kocho (KBP), protein density was $14.9 \%$ while the unsupplemented kocho was only $1.5 \%$ (Table 2 ). 


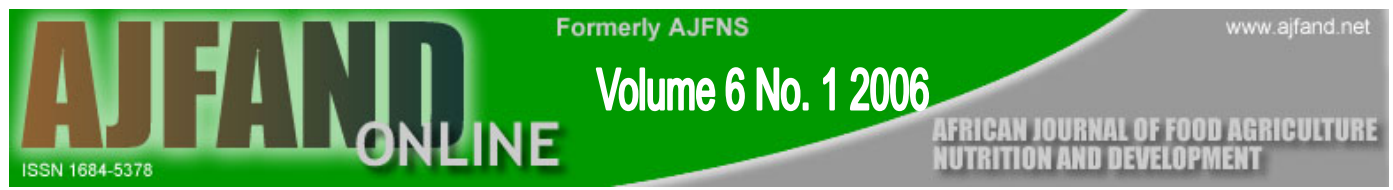

The essential amino acid pattern of the four formulations is shown in Table 3. The addition of kidney beans particularly increased the limiting concentrations of the essential amino acids lysine and threonine in the CBP (Tryptophan is amply provided by human milk, so less is required in the complementary food, and corn was able to supply the required quantity). All amino acids were increased markedly by adding beans to kocho because kocho alone contained only $1.5 \%$ protein. Table 4 presents the amount of the complementary foods needed to complement human milk to meet the $97.5^{\text {th }}$ percentile of protein and amino acid requirements for $6-8$ month-old infants.

The retinol activity equivalent (RAE) is based on the assumption that $12 \mu \mathrm{g}$ of dietary all-trans- $\beta$-carotene from food would be converted to the equivalent of $1 \mu \mathrm{g}$ retinol while $24 \mu \mathrm{g}$ of other dietary provitamin A carotenoids would be required to form $1 \mu \mathrm{g}$ retinol [18]. Assuming that $50 \%$ of the vitamin A activity contributed by pumpkin came from all-trans- 3 -carotene, and $50 \%$ from other dietary provitamin A carotenoids, the supplemented complementary foods both provided $54 \mu \mathrm{g} \mathrm{RAE} / 100 \mathrm{kcal}$ as fed.

\section{Sensory Evaluation}

Panelists were mothers and their children (13 \pm 8 months old) who had been introduced to semisolid foods at home, and were fed once per week at the nutrition unit of the Bushulo Health Center. All sensory attributes of the corn-based (CBP) and kocho-based (KBP) semi-solid complementary foods were rated favorably by the mothers (Table 5). Mean scores and standard deviations on the five point Hedonic scales ranged from 4.7 \pm 0.9 to $4.9 \pm 0.2$ indicating that the appearance, smell, taste and consistency were liked very much. There were no significance differences $(p>0.05)$ between the mothers' scores for sensory attributes of the CBP and KBP complementary foods or between those for traditional and supplemented complementary foods. Maternal interpretation of their child's responses indicated that neither the traditional nor the supplemented foods were significantly $(\mathrm{p}>0.05)$ preferred. Also, there were no significant differences $(p>0.05)$ in weight of leftover food, which was less than $3 \%$.

Mothers were asked about their intention to feed the corn or kocho-based complementary foods if price were not a consideration. More than $95 \%$ and $85 \%$ of the mothers who evaluated the CBP and KBP, respectively, expressed an intention to feed the supplemented foods to their children. No significant differences $(p>0.05)$ were observed between the mothers' intentions to feed the supplemented or traditional corn and kocho-based complementary foods.

\section{DISCUSSION}

Energy density

After six months children need to consume complementary foods of semisolid consistency with adequate energy and nutrient densities to supplement breast milk [1, 2, 19]. The child's capacity to obtain daily energy requirements depends on the energy

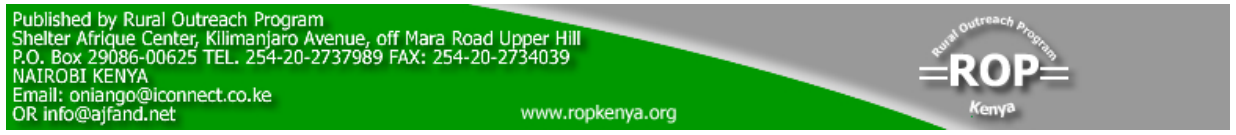


density of complementary foods, number of meals and the child's stomach capacity [1, $2,6,19]$. Increasing the energy density of cereal or root crop-based complementary foods becomes a major challenge due to the gelatinization of the starch during boiling, which requires addition of large amounts of water to have suitable viscosity [20]. For example, the weight of kocho in this study increased more than seven-fold after cooking into soft porridge. This creates an undesirable nutrient dilution effect unless other nutrient-dense ingredients are added. Furthermore, the increased fiber contributed by kidney bean and pumpkin required addition of more water during cooking to make porridge of a consistency that the mothers deemed suitable which is another reason for the reduced energy density of the legume- and pumpkin-supplemented foods.

Ways to increase energy density without increasing viscosity include adding oil, adding a non-gelatinous carbohydrate such as sugar, or using food processing techniques such as germination, fermentation, and liquefaction [21, 22. 23]. However, addition of too much oil or sugar is not recommended because of cost, and because energy alone might be increased without considering protein and micronutrient density of the final mixed complementary food [1]. The use of some avocado which has a high fat content would be a potential way to increase the energy densities of both CBP and KBP.

Using a community-based approach to develop complementary crop-based foods in Peru, it was reported that energy densities ranged from $0.39-2.33 \mathrm{kcal} / \mathrm{g}$ [24]. The products in this study were within the lower end of this range. To raise energy density to $2.33 \mathrm{kcal} / \mathrm{g}$, adding sugar, oil, or other ingredients would have been necessary, but this was not practical considering the resource limitations of the mothers in this study. In the present study, the low energy density of all the complementary foods would require three to four servings per day to meet the energy need for complementary foods for 6 - 8 month old breast-fed infants with average breast milk intake [2]. The 1998 WHO/UNICEF guidelines suggest that $269 \mathrm{kcal}$ per day would be required from complementary foods for 6 - 8 month old infants with average breast milk intakes, while an update to these guidelines suggests $202 \mathrm{kcal}$ per day would be adequate $[1,2]$. To provide $202 \mathrm{kcal}$ per day, more than $420 \mathrm{~g}$ per day of the legume-supplemented complementary porridges (as served) would be required. Lipid provided less than $10 \%$ of kcal in these complementary porridges. If expense were not prohibitive, adding foods containing more lipid to the porridges would be beneficial to increase energy density and provide needed nutrients [25].

\section{Protein density}

The protein concentration of CBP was improved more than $58 \%$ compared with the traditional corn food, and protein in KBP was increased nine-fold over traditional kocho (Figure 1). Legumes are valuable in the diet because they are relatively low cost and are good sources of protein, B vitamins and carbohydrates [15]. The protein densities of CBP and KBP ( $>14.7 \%$ ) were higher than the $5.5-10.7 \%$ protein densities reported the $6.3 \%$ recommended, and the amino acid patterns were improved $[24,26]$.

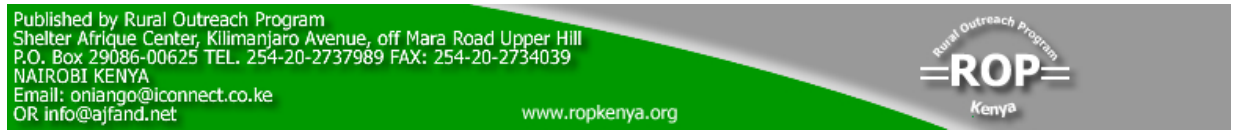


The amount of protein and other nutrients that should be provided by complementary foods is dependent on the amount of breast milk consumed [1, 2, 19, 23]. A 6 - 8 month old child weighing $6.4 \mathrm{~kg}$ with average breast milk intake needs to obtain approximately $4.2 \mathrm{~g}$ of protein from cereal-based complementary foods [1]. On a dryweight basis, $30 \mathrm{~g}$ of the CBP or KBP would meet this requirement, but $47 \mathrm{~g}$ of corn or $286 \mathrm{~g}$ of kocho would be needed. As the porridges are served, approximately $240 \mathrm{~g}$ of the CBP or KBP would be required and might feasibly be fed. However the more than $2 \mathrm{~kg}$ of traditional kocho porridge required to meet the protein needs would provide more than $1100 \mathrm{kcal}$ and be an impossible volume for a 6 - 8 month old infant to consume, illustrating why feeding young children tuber-based complementary foods contributes to severe malnutrition.

\section{Amino acid needs}

Much smaller amounts of the legume-supplemented complementary foods than of the traditional foods were needed to complement the amino acids in breast milk and to meet the $97.5^{\text {th }}$ percentile of the dietary requirement for essential amino acids. In the supplemented products, lysine, threonine and sulfur-containing amino acids needs could be met by 21.8 to $33.0 \mathrm{~g}$ (dry weight) of CBP or KBP. However, $272 \mathrm{~g}$ (dry weight) of kocho would be required for equivalent essential amino acids, which as served, would be much too large a volume for a $6-8$ month old infant to consume. While the distribution of essential amino acids in kocho is similar to the pattern required by children, the low protein concentration $(1.5 \mathrm{~g}$ protein $/ 100 \mathrm{~g}$ dry weight of kocho) makes it a very poor complementary food. If supplemented with higher protein foods such as legumes and by more energy-dense foods, kocho could be improved as an infant food in those communities that depend on it as the major household diet. Of course, the use of even small amounts of animal source foods would be beneficial [5]. Having a good mixture of amino acids (along with adequate intake of energy nutrients) is critical for better utilization of protein by young infants because their essential amino acid requirement is higher per kilogram of body weight, than older children $[14,19]$.

\section{Vitamin A Sources}

Often complementary food development focuses on improvement in protein and energy density. However, another objective of this study was to improve vitamin A intakes because of the documented high incidence of vitamin A deficiency in young children in Ethiopia [27]. The use of pumpkin improved the vitamin A density in CBP and KBP, compared with the unsupplemented corn and kocho diet, the improvement in the vitamin A value was more than 25 -fold in CBP and more than 180 -fold in KBP. The amounts of vitamin A necessary to prevent night blindness were evaluated by the Food and Nutrition Board, and an Estimated Average Requirement (EAR) of $112 \mu \mathrm{g}$ RAE/day was calculated for children aged 1 - 3 years [18]. However, based on the need to allow for adequate liver vitamin A stores, the Food and Nutrition Board established an EAR of $210 \mu \mathrm{g}$ RAE daily and a Recommended Dietary Allowance (RDA) of 300 $\mu \mathrm{g}$ RAE for children aged $1-3$ years in the United States and Canada [18]. A serving of the supplemented complementary foods providing $100 \mathrm{kcal}$ would provide about 


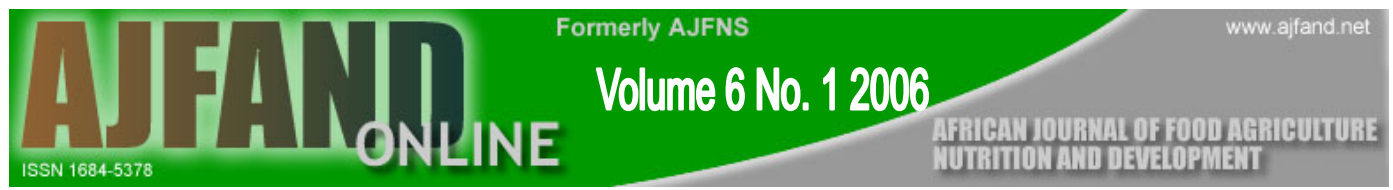

half the amount needed to prevent night blindness in the average child and about $25 \%$ of the EAR presumed to allow for accumulation of some liver stores.

\section{Sensory Evaluation}

Sensory evaluation of foods in a village community feeding setting can be complex, but knowing if a product is acceptable will be critical for project implementation. It was noted that dietary quality rather than quantity was a key aspect of complementary food development that needed improvement [28]. Focus group discussions were used to evaluate maternal preferences for consistency of complementary foods in Guatemala and found distinct preferences related to age and illness [29]. Involving mothers in nutrition education activities is recommended for improved nutritional status of young children, and the mothers in our study were enthusiastic about preparing the supplemented complementary foods [30].

Most of the theoretical base for conducting sensory evaluation relates to normal circumstances where food resources are adequate. Children who lack adequate food may eat foods eagerly due to hunger, which might not represent an accurate assessment of the acceptability of tested products using standard sensory evaluation procedures. Also, low-income caregivers in such situations may be inclined to give higher scores. This suggests the need for applicable methods for conducting sensory evaluation in low-income households with non-literate subjects. One method might be home-use testing for a period of time, with caregivers subsequently providing their evaluations individually or in small focus groups.

\section{CONCLUSION}

The addition of kidney beans enhanced the protein content of corn- and kocho-based complementary foods from $8.8 \mathrm{~g} / 100 \mathrm{~g}$ and $1.5 \mathrm{~g} / 100 \mathrm{~g}$ (dry weight) to $14.1 \mathrm{~g} / 100 \mathrm{~g}$ and $13.8 \mathrm{~g} / 100 \mathrm{~g}$, respectively. The pumpkin in CBP and KBP provided $54 \mu \mathrm{g}$ RAE per $100 \mathrm{kcal}$, increasing the Vitamin A value of the mixes by $25-$ and 180 -fold, respectively. Other crops such as kale, yellow sweet potatoes, avocado, and papaya that also grow in the area could be considered as alternative carotenoid sources.

There were no significant differences $(\mathrm{p}>0.05)$ in sensory acceptability of supplemented and corn-based or kocho-based foods by the panelists. Appearance, smell, taste, and consistency/mouth feel of all foods gained mean scores of 4.7 to 4.9, which corresponded to like very much. There were no significant differences $(\mathrm{p}>$ 0.05 ) in quantities of leftovers between the traditional and supplemented formulations. This study demonstrated successful use of locally available and affordable foods to enhance nutritional quality of complementary foods. 


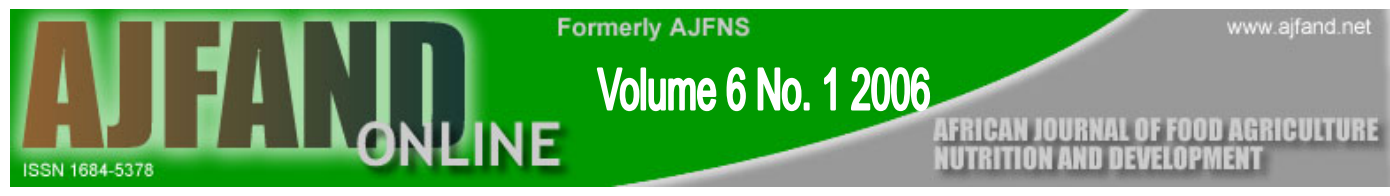

\section{Acknowledgements}

The authors appreciate the support of Winrock International, the Bushulo Health Clinic, the ACA/NORAD project, the Oklahoma Agricultural Experiment Station, and the women and children involved in the study. 


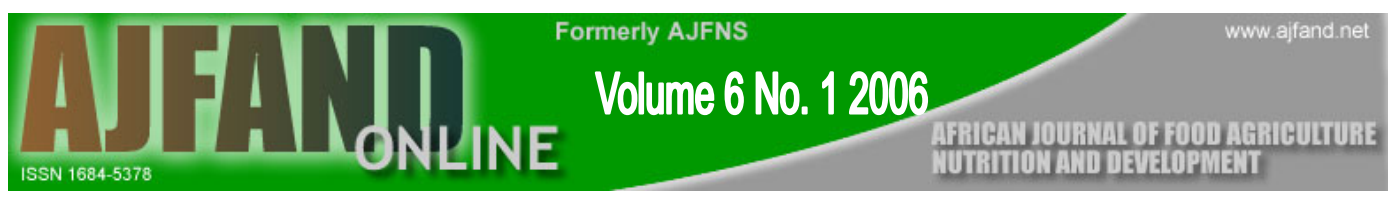

Table 1: Food items used to prepare the complementary foods

\begin{tabular}{llllll}
\hline Food Item (s) & $\begin{array}{l}\text { Corn } \\
(\mathrm{g})\end{array}$ & $\begin{array}{l}\text { Kocho } \\
(\mathrm{g})\end{array}$ & $\begin{array}{l}\text { Kidney } \\
\text { beans }(\mathrm{g})\end{array}$ & $\begin{array}{l}\text { Pumpkin } \\
(\mathrm{g})\end{array}$ & $\begin{array}{l}\text { Oil } \\
(\mathrm{g})\end{array}$ \\
\hline Corn: kidney beans: Pumpkin & 40 & - & 30 & 250 & 4.0 \\
Corn (traditional) & 100 & - & - & - & - \\
Kocho: kidney beans: pumpkin & - & 30 & 40 & 250 & 4.0 \\
Kocho (traditional) & 100 & - & - & - & - \\
\hline
\end{tabular}

Table 2: Nutrient densities of the traditional and supplemented complementary foods as served ${ }^{1}$

\begin{tabular}{lllll}
\hline Nutrient density & $\begin{array}{l}\text { Legume } \\
\text { supplemented } \\
\text { corn (CBP) }\end{array}$ & $\begin{array}{l}\text { Traditional } \\
\text { Corn (C) }\end{array}$ & $\begin{array}{l}\text { Legume } \\
\text { supplemented } \\
\text { Kocho (KB) }\end{array}$ & $\begin{array}{l}\text { Traditional } \\
\text { Kocho (K) }\end{array}$ \\
\hline $\begin{array}{l}\text { Energy density (Kcal/g wet } \\
\text { weight) }\end{array}$ & 0.48 & 0.53 & 0.46 & 0.49 \\
$\begin{array}{l}\text { Protein density (\% of energy) } \\
\text { Vitamin A density }{ }^{2}(\mu \mathrm{g}\end{array}$ & 14.7 & 8.4 & 14.9 & 1.5 \\
RAE/100 Kcal) wet weight & 53.5 & 2.1 & 54.4 & 0.3 \\
\hline
\end{tabular}

${ }^{1}$ Calculated values are based on chemical analysis for protein and vitamin A values and food table values for energy.

${ }^{2}$ Converted from total carotenes (assumed to be $50 \%$ all-trans-B carotene where $12 \mu \mathrm{g}=1 \mu \mathrm{g}$ Retinol Activity Equivalent (RAE) and 50\% other carotenoids where $24 \mu \mathrm{g}=1 \mu \mathrm{g}$ RAE) [18]. 


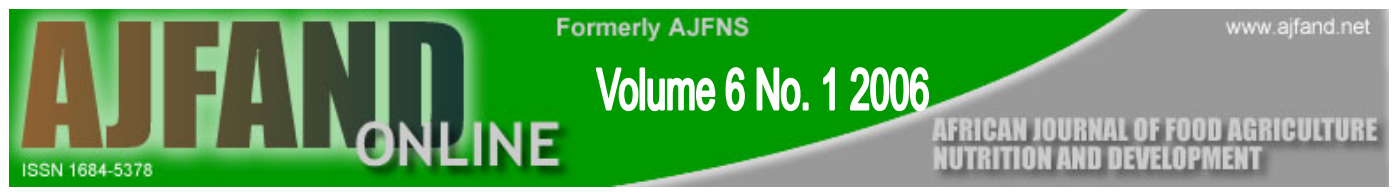

Table 3: Essential amino acid concentrations of the complementary foods ( $\mathrm{g} / 100 \mathrm{~g}$ protein) ${ }^{1}$

\begin{tabular}{|c|c|c|c|c|}
\hline $\begin{array}{l}\text { Essential amino } \\
\text { acids }\end{array}$ & $\begin{array}{l}\text { Legume- } \\
\text { supplemented } \\
\text { corn }\end{array}$ & $\begin{array}{l}\text { Traditional } \\
\text { corn }\end{array}$ & $\begin{array}{l}\text { Legume- } \\
\text { supplemented } \\
\text { kocho }\end{array}$ & $\begin{array}{l}\text { Traditional } \\
\text { kocho }\end{array}$ \\
\hline Histidine & 2.95 & 3.12 & 2.91 & 2.06 \\
\hline Isoleucine & 4.17 & 3.63 & 4.38 & 4.12 \\
\hline Leucine & 8.44 & 11.68 & 7.49 & 7.56 \\
\hline Lysine & 5.34 & 2.78 & 6.27 & 5.50 \\
\hline $\begin{array}{l}\text { Methionine + } \\
\text { cysteine }\end{array}$ & 2.71 & 4.14 & 2.29 & 3.44 \\
\hline $\begin{array}{l}\text { Phenylalanine }+ \\
\text { tyrosine }\end{array}$ & 7.84 & 7.71 & 7.96 & 6.87 \\
\hline Threonine & 3.35 & 3.01 & 3.53 & 2.75 \\
\hline Tryptophan & 0.16 & 0.74 & 1.87 & 2.75 \\
\hline Valine & 4.94 & 4.88 & 5.02 & 5.50 \\
\hline
\end{tabular}




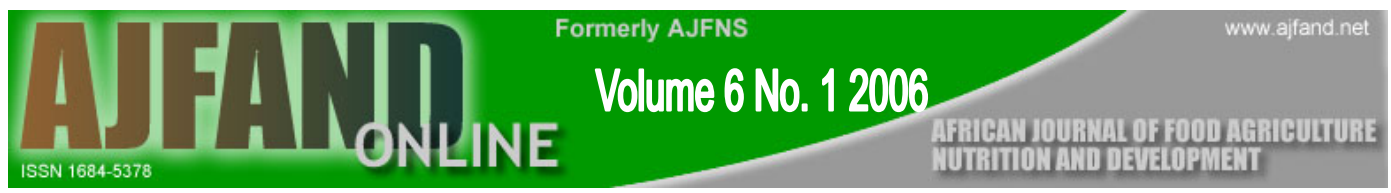

Table 4: Amounts of complementary food (dry weight) needed to complement protein and amino acids in breast milk for a 6-8 month old growth-retarded infant $^{1}$

\begin{tabular}{|l|cccc|}
\hline & $\begin{array}{c}\text { Legume- } \\
\text { supplemented } \\
\text { Corn (CBP) }\end{array}$ & $\begin{array}{c}\text { Traditional } \\
\text { Corn }\end{array}$ & $\begin{array}{c}\text { Legume- } \\
\text { supplemented } \\
\text { Kocho (KBP) }\end{array}$ & $\begin{array}{c}\text { Traditional } \\
\text { Kocho }\end{array}$ \\
\hline $\begin{array}{l}\text { Food needed to complement } \\
\text { protein of breast milk }\end{array}$ & $\begin{array}{c}\text { g/day } \\
\text { g/day }\end{array}$ & $\begin{array}{c}\text { g/day } \\
\text { g/day }\end{array}$ & 285.9 \\
$\begin{array}{l}\text { Food needed to complement } \\
\text { amino acids of breast milk }\end{array}$ & & & & \\
$\quad \begin{array}{l}\text { Lysine } \\
\text { Threonine }\end{array}$ & 29.6 & 88.8 & 25.1 & \\
$\quad$ Methionine \& Cysteine & 22.5 & 41.1 & 21.8 & 272.0 \\
\hline
\end{tabular}

${ }^{1}$ Body wt of growth retarded infant assumed to be $6.4 \mathrm{~kg}$ [1].

${ }^{2}$ Protein recommendation from cereal based complementary foods assuming $25^{\text {th }}$ percentile of breast milk intake is $0.65 \mathrm{~g} /(\mathrm{kg} / \mathrm{d})$ [26].

${ }^{3}$ Estimated additional amino acid needed to achieve the $97.5^{\text {th }}$ percentile of the amino acid requirement assuming $25^{\text {th }}$ percentile of breast milk intake: lysine $34 \mathrm{mg} /(\mathrm{kg} / \mathrm{d})$; threonine $17 \mathrm{mg} /(\mathrm{kg} / \mathrm{d})$; methionine \& cysteine $16 \mathrm{mg} /(\mathrm{kg} / \mathrm{d})[26]$. 


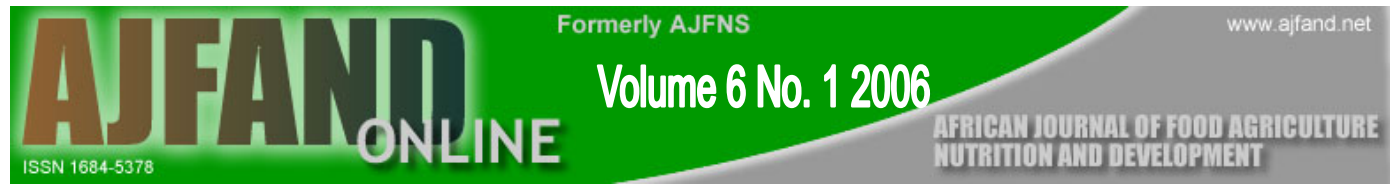

Table 5: Maternal acceptability ratings ${ }^{1}$ of the sensory attributes of the complementary foods ${ }^{2}$.

\begin{tabular}{|l|l|l|l|l|}
\hline $\begin{array}{l}\text { Sensory } \\
\text { Attrubute }\end{array}$ & $\begin{array}{l}\text { Legume- } \\
\text { supplemented } \\
\text { Corn (CBP) } \\
(\mathrm{n}=30)\end{array}$ & $\begin{array}{l}\text { Traditional } \\
\text { Corn }\end{array}$ & $\begin{array}{l}\text { Legume- } \\
\text { supplemented } \\
\text { Kocho } \\
(\mathrm{n}=28)\end{array}$ & $\begin{array}{l}\text { Traditional } \\
\text { Kocho }\end{array}$ \\
\hline Appearance & $4.7 \pm 0.8$ & $4.9 \pm 0.4$ & $4.7 \pm 0.8$ & $4.7 \pm 0.9$ \\
\hline Smell & $4.8 \pm 0.8$ & $4.9 \pm 0.2$ & $4.7 \pm 0.7$ & $4.8 \pm 0.5$ \\
\hline Taste & $4.7 \pm 0.8$ & $4.9 \pm 0.4$ & $4.7 \pm 0.7$ & $4.8 \pm 0.6$ \\
\hline $\begin{array}{l}\text { Consistency/ } \\
\text { Mouth Feel }\end{array}$ & $4.7 \pm 0.9$ & $4.9 \pm 0.3$ & $4.9 \pm 0.3$ & $4.9 \pm 0.4$ \\
\hline
\end{tabular}

${ }^{1}$ Mean Hedonic score \pm standard deviation. On a 5 point scale " 5 " was like very much, "4" like a little, " 3 " neither like nor dislike, " 2 " dislike a little, and " 1 " dislike very much.

${ }^{2}$ No significant differences $(\mathrm{p}>0.05)$ between supplemented and traditional foods 


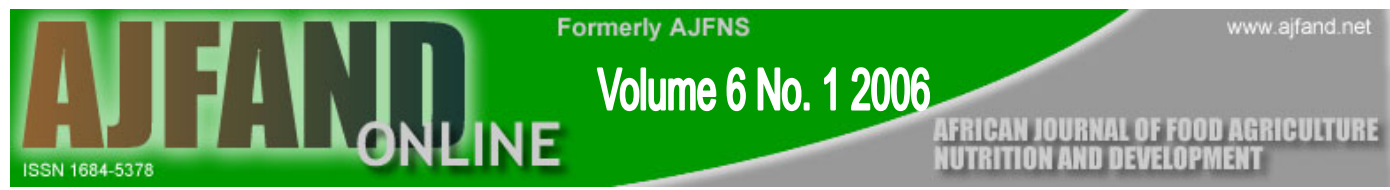

\section{REFERENCES}

1. WHO/UNICEF Complementary Feeding of Young Children in Developing Countries: A Review of Current Scientific Knowledge. WHO/NUT/98.1. World Health Organization, Geneva. 1998. 1-228.

2. Dewey KG and KH Brown Update on Technical Issues Concerning Complementary Feeding of Young Children in Developing Countries and Implications for Intervention Programs. Food Nutr. Bull. 2003; 24: 5-28.

3. Lutter CK, Dewey KG and JL Rosado Nutrient Composition for Fortified Complementary Foods - Proceedings of a Technical Consultation Held at the Pan American Health Organization, Washington, DC, October 4-5, 2001 - Foreword. J. Nutr. 2003; 133: 2940S.

4. Krebs NF and $\mathbf{J}$ Westcott Zinc and Breastfed Infants: If and When Is There a Risk of Deficiency? Adv. Exp. Med. Biol. 2002; 503: 69-75.

5. Neumann C, Harris DM and LM Rogers Contribution of Animal Source Foods in Improving Diet Quality and Function in Children in the Developing World. Nutr. Res. 2002; 22: 193-220.

6. Michaelsen KF and $\mathbf{H}$ Friis Complementary Feeding: A Global Perspective. Nutrition 1998; 14: 763-766.

7. Urga K and HV Narasimha Phytate : Zinc and Phytate $x$ Calcium : Zinc Molar Ratios in Selected Diets of Ethiopians. Bull.Chem. Soc. Ethiopia 1998; 12: 1-7.

8. Hurrell RF Influence of Vegetable Protein Sources on Trace Element and Mineral Bioavailability. J.Nutr. 2003; 133: 2973S-2977S.

9. Mbithi-Mwikya S, Van Camp J, Mamiro PRS, Ooghe W, Kolsteren P and A Huyghebaert Evaluation of the Nutritional Characteristics of a Finger Millet Based Complementary Food. J.Agric. Food Chem. 2002; 50: 3030-3036.

10. WHO Global Strategy for Infant and Young Child Feeding (A54/INF.DOC./4). Geneva: World Health Organization, 2001: 1-5.

11. Bekele A and Y Berhane Weaning in Butajira, South Ethiopia: A Study on Mothers' Knowledge and Practice. Ethiop. Med. J. 1998; 36: 37-45.

12. Wolde-Gebriel A Determinants of Weaning Practice. Ethiop. J. Hlth. Develop. 2000; 24: 183-189.

13. Pelto GH, Levitt $\mathbf{E}$ and $\mathbf{L}$ Thairu Improving Feeding Practices: Current Patterns, Common Constraints, and the Design of Interventions. Food Nutr. Bull. 2003; 24: 24-82. 


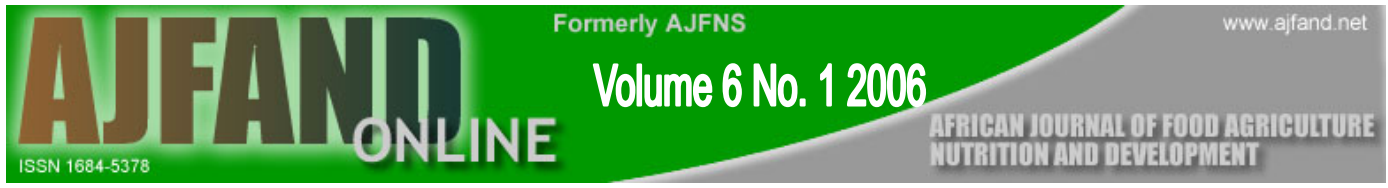

14. Marero LM, Payumo EM, Librando EC, Lainez WN, Gopez MD and S Homma Technology of Weaning Food Formulations Prepared from Germinated Cereals and Legumes. J. Food Sci. 1988; 53: 1391-1395.

15. Latham MC Human Nutrition in the Developing World: FAO Food and Nutrition Series- 29. 1997. Rome, Food and Agriculture Organization of the United Nations. 1-492

16. Stone H and JL Sidel Sensory Evaluation Practices. 1993; San Diego: Academic Press.

17. SPSS Statistical Program for Social Sciences (Version 11.0). 2001; Chicago: SPSS, Inc.

18. Panel on Micronutrients Standing Committee on the Scientific Evaluation of Dietary Reference Intakes, Food and Nutrition Board, Institute of Medicine. Vitamin A. In: Dietary Reference Intakes for Vitamin A, Vitamin K, Arsenic, Boron, Chromium, Copper, Iodine, Iron, Manganese, Molybdenum, Nickel, Silicon, Vanadium, and Zinc. 2001; Washington, D.C.: National Academy Press. $82-161$.

19. Dewey KG Nutrient Composition of Fortified Complementary Foods: Should Age-Specific Micronutrient Content and Ration Sizes Be Recommended? J. Nutr. 2003; 133: 2950S-2952S.

20. Egounlety M, Aworh OC, Akingbala JO, Houben JH and MC Nago Nutritional and Sensory Evaluation of Tempe-Fortified Maize-Based Weaning Foods. Inter. J. Food Sci. Nutr. 2002; 53: 15-27.

21. Mugula JK and M Lyimo Evaluation of the Nutritional Quality and Acceptability of Fingermillet-Based Tempe as Potential Weaning Foods in Tanzania. Inter. J. Food Sci. Nutr. 1999; 50: 275-282.

22. Treche S and IL Mbome Viscosity, Energy Density and Osmolality of Gruels for Infants Prepared from Locally Produced Commercial Flours in Some Developing Countries. Inter. J. Food Sci. Nutr. 1999; 50: 117-125.

23. Bennett VA, Morales E, Gonzalez J, Peerson JM, de Romana GL and KH Brown Effects of Dietary Viscosity and Energy Density on Total Daily Energy Consumption by Young Peruvian Children. Amer. J. Clin. Nutr. 1999; 70: 285291.

24. Kanashiro HC, Fukumoto M, Bentley ME, Jacoby E, Verzosa C and KH Brown Use of Recipe Trials and Anthropological Techniques for the Development of A Home-Prepared Weaning Food in the Central Highlands of Peru. J. Nutr. Educ. 1991; 23: 30-35. 


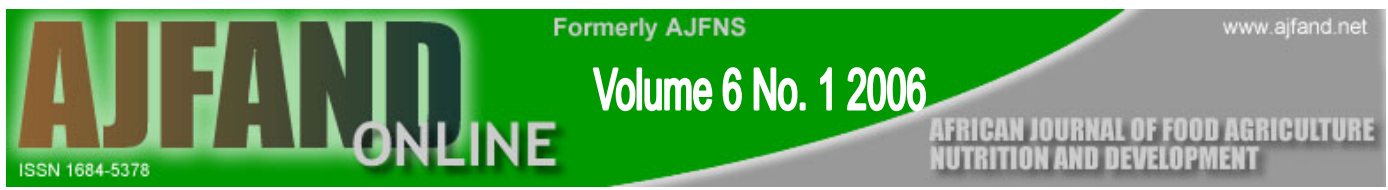

25. Uauy $\mathbf{R}$ and $\mathbf{C}$ Castillo Lipid Requirements of Infants: Implications for Nutrient Composition of Fortified Complementary Foods. J. Nutr. 2003; 133: 2962S2972S.

26. Reeds PJ and PJ Garlick Protein and Amino Acid Requirements and the Composition of Complementary Foods. J. Nutr. 2003; 953S-2961S.

27. Haidar J, Tsegaye D, Mariam DH, Tibeb HN and NM Muroki Vitamin A Supplementation on Child Morbidity. East African Med. J. 2003; 80: 17-21.

28. Lutter CK and JA Rivera Nutritional Status of Infants and Young Children and Characteristics of Their Diets. J. Nutr. 2003; 133: 2941S-2949S.

29. Parker ME, Schroeder DG, Begin F and E Hurtado Maternal Preferences for Consistency of Complementary Foods in Guatemala. Food Nutr. Bull. 1998; 19: 6-12.

30. Muroki NM, Maritim GK, Karuri EG, Tolong HK, Imungi JK, KogiMakau W, Maman S, Carter E and AN Maretzki Involving Rural Kenyan Women in the Development of Nutritionally Improved Weaning Foods: Nutribusiness Strategy. J. Nutr. Educ. 1997; 29: 335-342, 1997. 